\title{
Polityka Imperium Otomańskiego wobec chrześcijan i Cerkwi prawosławnej na terenie byłego Bizancjum na przełomie XV i XVI wieku
}

\author{
Marcin Mironowicz \\ Uniwersytet w Białymstoku \\ Polska \\ marcin.mironowicz5@gmail.com
}

\begin{abstract}
Marcin Mironowicz, The Ottoman Empire's Policy Toward Christians and the Orthodox Church in the Former Byzantine Empire at the turn of the Fifteenth and Sixteenth Century, Elpis, 18 2016: 153-156.

Abstract: This article presents the Ottoman Empire's presuppositions regarding its former Byzantine Empire residents. Special attention is given to the Orthodox Church's situation, and patriarchal rights and privileges. It also depicts the career path of the subdued Greeks in the Ottoman state.

Streszczenie: W artykule przedstawione są główne założenia polityki Imperium Ottomańskiego w stosunku do mieszkańców Bizancjum. Szczególną wagę zwrócono na sytuację Kościoła prawosławnego, na prawa i przywileje patriarchy. Ukazano ścieżki kariery podbitych greków w państwie osmańskim.
\end{abstract}

Keywords: Ottoman Empire, Orthodoxy, patriarch

Słowa kluczowe: Imperium Otomańskie, Prawosławie, patriarcha

W 1453 r. Imperium Osmańskie zdobyło Konstantynopol. W ciągu kilkuset następnych lat Bizancjum znajdowało się w niewoli tureckiej. Władcą Imperium Osmańskiego był sułtan, zwany także padyszachem, kalifem, szachinszachem czy „imperatorem Wschodu i Zachodu”. Wola sułtana była święta, a jedynym jej ograniczeniem był szariat. Sułtan był władcą despotycznym, „panem ludzkich karków”, który wszystkich poddanych traktował jak niewolników. Państwo i cała ziemia w obrębie państwa uznawana była za dziedziczną własność dynastii Osmanów. Sułtan rządził z pomocą zastępu urzędników. Najwyższym był wielki wezyr. W sferze gospodarczej Imperium Osmańskie było państwem łupieskim, które swój złoty okres przeżywało w okresie grabienia podbijanych terytoriów.

Grabieży doświadczyły też miasta bizantyjskie. Zgodnie z muzułmańską tradycją miasto, które odmówiło poddania się, traciło swoje świątynie, mieszkańcy tracili wolność, a w mieście przez trzy dni nieograniczonej niczym grabieży dopuszczali się żołnierze ottomańscy. Następnie, w miarę normalne życie w podbitym kraju, było możliwe pod warunkiem spełnienia narzuconych przez Portę zabowiązań. Społeczeństwo greckie musiało opłacać podatek pogłówny w formie pieniężnej, tzw. dżizję ${ }^{1}$. Od czternastego roku życia wszyscy Grecy zabowiązani byli wnosić ten podatek - najbiedniejsi płacili jeden dukat w ciągu roku, bogatsi dwa dukaty, a najbogatsi 4 dukaty. Kupcy płacili też podatki w zależnosci od wartości towarów jakie sprzedawali bądź

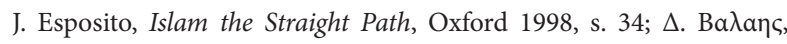

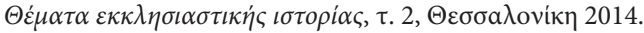

przywozili z innych krajów. Wniesiony podatek dokumentował kwit, którego kolor każdego roku był inny. Kwit zawsze trzeba było mieć przy sobie i w razie potrzeby pokazywać do kontroli. Jeśli ktoś go nie miał mógł być pociągnięty do ponownej opłaty podatku. Osoba, która uiściła dżizję była chroniona przez Portę i stawała się takim samym poddanym sułtana jak muzułmanin. Od podatku były zwolnione chrześcijańskie kobiety i ci Grecy, którzy pełnili służbę morską na rzecz sułtana. Zapłacony podatek zwalniał też od służby wojskowej². Wielu chrześcijan greckich żyło z pracy na roli. Turcy nakładali na nich oprócz podatku pogłównego także podatek od ziemi - charadiz $\dot{z}^{3}$ Opłacenie tej daniny stanowiło podstawę dziedziczenia ziemi.

Najbardziej upokarzającym zobowiązaniem był specjalny pobór dzieci z chrześcijańskich rodzin - dewszirme. Co pięć lat w danej prowincji odbywała się branka chłopców ${ }^{4}$. Przybyły wysłannik Porty otrzymywał od starszyzny spis wszystkich dzieci płci męskiej w wieku powyżej 7 lat, za wyjątkiem żonatych młodzieńców. Ojciec, który próbował ukryć syna, poddawany był torturom tak długo, dopóty nie uwolnił potomka. Jeśli liczba dzieci była duża, niektórzy, głównie bogaci, mieli możliwość wykupienia swego dziecka. Branek nie przeprowadzano w Konstantynopolu i tych krajach, które dobrowolnie przyjęły zwierzchnictwo sułtana (Węgry, Egipt). Zwerbowani chłopcy mieli spe-

\footnotetext{
А. П. Лебедев, История греко-восточной иеркви под властью турок, С. Петербург 1902, с. 156.

S. Runciman, Dzieje wypraw krzyżowych, Warszawa 1987, s. 32.

4 J. Pajewski, Buńczuk i koncerz: Z dziejów wojen polsko-tureckich, Warszawa 1978, s. 28.
} 
cjalny strój i byli kierowani do Konstantynopola. Tam ich obrzezywano i nawracano na islam. W ciągu kilkunastu lat nie mieli kontaktu ze światem zewnętrznym. Część z nich kierowano do szkół, w których uczyli sie perskiego, arabskiego, tureckiego. Inni przyuczali się do pracy w kuchni, ogrodach bądź uczyli się strzelać z łuku. Najbardziej wykształconych kierowano później na dwór sułtana. Część trafiała do piechoty tureckiej - janczarów bądź kawalerii - spahisi. W wojsku oturczone chrześcijańskie dzieci niekiedy osiągały wysokie stanowiska: generałów - agi, admirałów floty. Ci, którzy służyli na dworze sułtańskim niekiedy obejmowali posadę rządzących prowincją - baszów. Branek z chłopców chrześcijańskich zaprzestano na mocy ukazu Murata IV (1623-1640) i ukazem z 1685 r.

Niektórzy Grecy potrafili w okresie niewoli tureckiej zajmować się tym, czym zajmowali się od dawna. Pomimo, że Porta Ottomańska wyłączyła chrześcijan z obowiązku służby wojskowej to w rękach chrześcijan Greków pozostawała opłacana flota. Tylko oni znali się na żegludze i budowie statków. Grecy zajmowali się też rzemiosłem, opanowali handel. W literaturze dominuje pogląd, że „wszystcy chrześcijanie żyją w Imperium Osmańskim ze wszystkimi wolnościami i w spokoju”, strach zaś odczuwali ci, którzy byli na służbie u sułtana ${ }^{5}$.

Instytucją, która po zdobyciu Konstantynopola pozostała prawie nietknięta, był Kościół ${ }^{6}$. Dowodem tego jest fakt, że Mehmed II (1432-1481) wkrótce po zwycięstwie dokonał obsadzenia tronu patriarszego, który wakował przez kilka lat. 6 stycznia 1454 r. odbył się sobór, na którym sułtan obrał patriarchą mnicha Gennadiusza Scholariosa (1405-1472) - erudytę i hezychastę. Wpływ na ten wybór mieli greccy współpracownicy sułtana.

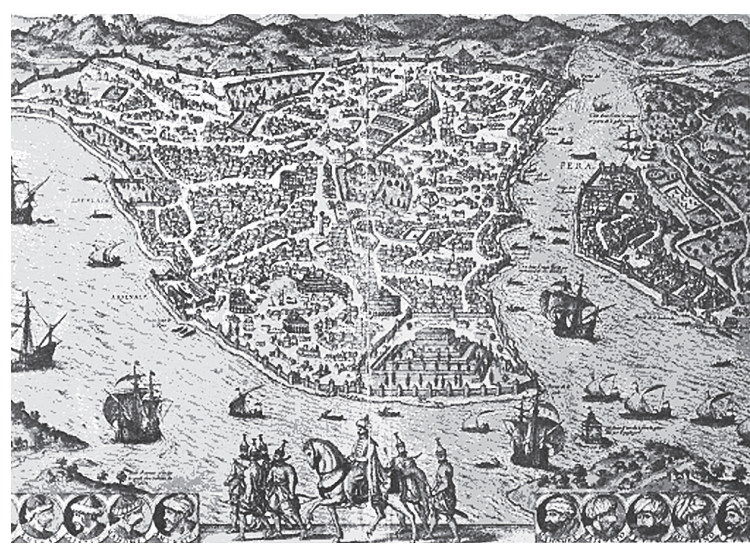

Konstantynopol w XVI w.

W firmanie ${ }^{7}$ Mehmed II określił prawa dla chrześcijan ${ }^{8}$. Zgodnie z dokumentem na czele greckiej cerkwi stał

\footnotetext{
А. П. Лебедев, История греко-восточной церкви..., с. 154.

ks. M. Bendza, Kontynuacja Romeosinis w okresie turkokracji, [w:] Bizancjum, Prawosławie, Romantyzm. Tradycja Wschodnia w Kulturze XIX w., red. J. Ławski i K. Korotkich, Białystok 2004, s. 86.

Firman - określenie oficjalnych dokumentów wystawianych przez sułtana. Firman zawierał osobisty pisemny rozkaz i był pieczętowany sułtańską pieczęcią.

А. П. Лебедев, История греко-восточной церкви..., с. 100
}

patriarcha, działał synod. Patriarcha został ogłoszony millet-paszą ${ }^{9}$ i odpowiadał jedynie przed sułtanem. Dla chrześcijan był urzędnikiem państwowym, który zarządzał całą strukturą hierarchii prawosławnej - siecią metropolii, biskupstw, monasterów, starożytnych patriarchatów. Do niego należało powoływanie i odwoływanie, za akceptacją Wysokiej Porty, biskupów. Posiadał dyscyplinarną i karną władzę nad klerem. Wszystkie jego decyzje posiadały charakter soborowy. Przy patriarsze obradował Święty Synod ${ }^{10}$. Patriarcha i biskupi przed przyjęciem święceń otrzymywali od sułtana beraty. Beraty nadawali patriarsze i biskupom władzę świecką i sądową nad chrześcijanami. Szczególnie uprawnienia nadawały beraty patriarchom powoływał on i odwoływał biskupów, archimandrytów, zarządzał zbory pieniężne, ogłaszał świętych, rozstrzygał spory dotyczące życia małżeńskiego lub religijnego wiernych, mógł nałożyć anafemę, zabronić wejścia do cerkwi, pochówku. Patriarcha mógł przemieszczać się konno $\mathrm{w}$ asyście straży ${ }^{11}$. Prawa $\mathrm{w}$ stosunku do wiernych czynią prawdziwym określenie, że patriarcha był nie tylko przywódcą duchownym, ale też „wodzem nacji greckiej”. Wszystko, co dotyczyło rządu nad chrześcijanami w sensie duchowym podlegało woli patriarchy, władza turecka tym się nie zajmowała. Patriarcha miał prawo zwoływać tzw. „zebrania narodowe”, na których były poruszane sprawy szkolnictwa, budowy szpitali. Patriarcha dawał pozwolenie na budowę szkół, sprawował nadzór nad wydawnictwem książek ${ }^{12}$. Status metropolitów i biskupów w państwie był wysoki i wpływowy. Biskupi brali udział w zarządzaniu prowincjonalnym - medżlisie (samorządzie, radzie), co powodowało, że byli przedstawicielami tureckiej władzy terytorialnej ${ }^{13}$. Fakt ten tłumaczy dobre kontakty między biskupami i świeckimi. Dokonywane transakcje i operacje często były opieczętowane pieczęcia biskupią. Wszelkie zastrzeżenia odnośnie władzy były kierowane do arcybiskupa i ten przedstawiał je na posiedzeniu medżlisy. Postępowanie takie doprowadzalo do nadużyć finansowych biskupów. Berat dawał im niczym nieograniczoną władzę nad wiernymi. Wierni utrzymywali hierarchię płacąc narzucone podatki. Za niewywiązanie się z powinności mogli być skierowani do monasteru, zamknięci w celi lub posądzeni o odejście od zmysłów ${ }^{14}$.

Chrześcijanie zachowali część swoich cerkwi (zazwyczaj połowa cerkwi była zamieniona w meczety, zaś druga połowa pozostała w ręku prawosławnych $)^{15}$. Wszystkie powinności religijne odprawiano swobodnie: śluby i po-

\footnotetext{
W państwie osmańskim najważniejszymi w systemie milletów był millet muzułmański, grecki (Rum millet), żydowski i ormiański. Każdy millet posiadał suwerena o dość szerokich kompetencjach, etnarchę (gr. $\dot{\varepsilon} \theta$ vá $\chi \eta \varsigma$ - władca narodu). Najczęściej był nim przywódca religijny (np. prawosławny Patriarcha Konstantynopola), który podlegał bezpośrednio sułtanowi. Millety miały sporo władzy - ustanawiały własne prawa, zbierały i rozdzielały własne podatki. Wszystko czego od nich wymagano to lojalność wobec Imperium.

10 А. П. Лебедев, История греко-восточной иеркви..., с. 101.

11 А. П. Лебедев, История греко-восточной иеркви..., с. 111.

12 А. П. Лебедев, История греко-восточной иеркви..., с. 111.

13 А. П. Лебедев, История греко-восточной иеркви..., с. 113.

14 А. П. Лебедев, История греко-восточной иеркви..., с. 115.

15 S. Runciman, Upadek Konstantynopola, Warszawa 1994, s. 179.
} 
grzeby, świętowanie Wielkanocy we wszystkich miastach i wsiach (symbolem były otwarte wrota Fanaru, które pozostawały niezamknięte $\mathrm{w}$ przeciagu trzech paschalnych nocy). Wszyscy duchowni byli zwolnieni od podatku. Patriarcha i biskupi byli chronieni przez Turków przed wrogiem zewnętrznym. Pozostali chrześcijanie opłacali podatek pogłówny, w zamian za co gwarantowano im swobodę kultu i zachowanie świątyń. Mehmed II, w którym płynęła grecka krew, daleki był od fanatyzmu religijnego i otaczał się chrześcijanami - Grekami. Koran również nakazywał tolerancję wobec ludzi biblii (chrześcijanie i żydzi). Turcy darzyli szacunkiem Chrystusa i Bogurodzicę. Znany jest przekaz, że za ośmieszanie Chrystusa turecki sędzia ukazał więzieniem i batami Żyda, a Turek, który obraził Chrystusa został skazany na ścięcie głowy. Turcy chodzili po wodę święconą do chrześcijan, odwiedzali groby chrześcijańskich świętych, biorąc z nich mirro i św. oleje. Prosili duchowieństwo chrześcijańskie o modlitwę, czasem zwracali się do patriarchy o modlitwę za państwo, która miała je uchronić przed klęską bądź niebezpieczeństwem.

Przywileje polityczne patriarchatu miały równie szeroki zakres. Patriarchat przez Wysoką Portę był traktowany jako autonomiczne państwo kościelne ${ }^{16}$. Patriarcha posiadał prawo do nakładania zobowiązań na kler i ludzi świeckich. Decydował o prawie rodzinnym i cywilnym chrześcijan. Chrześcijanie szukali sprawiedliwości w sądach kościelnych. Sądy patriarsze opierały się o skodyfikowane prawo rzymskie „Basilica”, twórcami którego był Bazyli Macedończyk (867-886) i jego syn Leon VI Mądry (886-911).

Przywileje przyznane patriarchatowi przede wszystkim miały służyć interesom Imperium Ottomańskiego. Patriarcha był odpowiedzialny za chrześcijan przed sułtanem: „Nie z własnej woli (był) gwarantem stałej subordynacji chrześcijan przed okupantem"17. Przywileje sułtana, mimo zewnętrznej łaskawości, często były złudne. Pozycja patriarchy (ethnarchy) i wszystkich jego wspólpracowników była trudna i niebezpieczna. Sułtan wymagał przestrzegania swego świętego prawa, jego wola była najwyższym prawem i najmniejsza niesurbordynacja stawała się przyczyną niejednokrotnych mordów na patriarchach i biskupach przez cały okres turkokracji18. Przedstawione fakty ukazują nam obraz zniewolonego państwa jako „państwa cerkiewnego" w ramach Imperium Osmańskiego. W XVI w. greccy historycy patriarchę i sułtana określali mianem pan i król ( $a v \theta \varepsilon v \tau \eta \dot{~ i ~} \beta a \sigma ı \lambda \varepsilon \dot{\varepsilon} a \varsigma$ ). Obok na-

\footnotetext{
16 G. Metallenos, Tourkokratia, Hoi Hellenes sten Othomanike autokratoria, Ateny 1988, s.66.

17 G. Metallenos, Tourkokratia, Hoi Hellenes sten Othomanike autokratoria, Ateny 1988, s. 68.

18 ks. M. Bendza Kontynuacja Romeosinis w okresie turkokracji s. 87-88.
}

zwy Porta Ottomańska używali dla określenia patriarchatu Porta Fanara ${ }^{19}$.

Mehmed II spowodował, że został wybrany nowy patriarcha konstantynopolitański. Początkowo jego siedzibą był sobór św. Apostołów znajdujący się na czwartym wzgórzu Konstantynopola. W 1456 r. siedziba została przeniesiona do dzielnicy Fanar do monasteru Panmakaristos, gdzie mieści się do dzisiaj. Po utracie niepodległości patriarchat stał się centrum wokól której skupiła się bizantyjska inteligencja i arystokracja. W stolicy Porty chrześcijanie czuli się najbardziej bezpiecznie. W końcu XVI w. W Konstantynopolu żyło okolo 100 tys. chrześcijan.

Tam, gdzie Turków zamieszkiwało mało życie greckiej ludności nie uległo istotnym zmianom w porównaniu do czasów bizantyjskich. Lokalną władzę w prowincjach Porta przekazywała Greckom. Stawali się oni pośrednikami między władzą turecką, a miejscową podbitą ludnością. Zazwyczaj na czele lokalnego zgromadzenia wybierano arystokratę bądź powszechnie znaną osobe. Stanowisko takie określano mianem prymatów ( kodżabasza), archontów, dimogerontów Byli oni rozliczani za utrzymanie lokalnego spokoju i pokoju, a także lojalności podległych im mieszkańców ${ }^{20}$.

W XVI w. utworzyła się nowa klasa Greków- fanariotow. Byli oni wszechstronnie wyksztalceni, obrotni i zajmujący wysokie stanowiska w rządzie tureckim. Przykładem fanarioty może być postać Michała Kantakuzina ${ }^{21}$. Turcy nie znali greki. Z tego powodu to Grecy zajmowali stanowiska tłumaczy (dragomanów) na różnych szczeblach władzy w państwie osmańskim. Często dragoman posiadal większy realny wpływ na sprawę, aniżeli sam pasza ${ }^{22}$.

Grecy sprawowali funkcje hospodarów w Mołdawii i Wołoszczyźnie. Być może dlatego duża część Greków niższego i średniego stanu wyjechała w tym czasie do tych krajów. Grecki historyk Paparigopulu pisał że, „Rumunia w XVIII w. zamienila się w grecką kolonię"(146-148). Nieznany z imienia muzyk z Parmy który przebywał przez pięć lat na służbie u Turków stwierdził, że Turcy nie niepokoją w Konstantynopolu nikogo z powodu religii i pozwalają zachować w spokoju wiarę chrześcijańską" ${ }^{23}$. Z kolei badacz dziejów Imperium Osmańskiego określił sytuację tego kresu następującymi słowami „zwycięzcy uzależnili się od zwyciężonych", miał on na myśli głównie wpływy w kierowaniu Impwerium wykształconych Greków.

\footnotetext{
19 А. П. Лебедев, История греко-восточной иеркви..., с. 121.

20 А. П. Лебедев, История греко-восточной и,еркви..., с. 133.

21 А. П. Лебедев, История греко-восточной иеркви..., с. 138.

22 А. П. Лебедев, История греко-восточной церкви..., с. 140.

23 J. W. Zinkeisen, Geschichte des osmanischen Reiches in Europa, B. II, Hamburg 1854, s. 472.
} 


\section{Bibliografia}

ks. Bendza M., Kontynuacja Romeosinis w okresie turkokracji, [w:] Bizancjum, Prawosławie, Romantyzm. Tradycja Wschodnia w Kulturze XIX w., red. J. Ławski i K. Korotkich, Białystok 2004. Pajewski J., Buńczuk i koncerz: Z dziejów wojen polsko-tureckich, Warszawa 1978.

Runciman S., Dzieje wypraw krzyżowych, Warszawa 1987.

Runciman S., Upadek Konstantynopola, Warszawa 1994.

Esposito J., Islam the Straight Path, Oxford 1998.
Zinkeisen J. W., Geschichte des osmanischen Reiches in Europa, B. II, Hamburg 1854

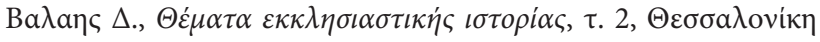
2014.

Metallenos G., Tourkokratia, Hoi Hellenes sten Othomanike autokratoria, Ateny 1988.

Лебедев А. П., История греко-восточной церкви под властью турок, С. Петербург 1902.

Rozmiar artykułu: 0,5 arkusza wydawniczego 